\title{
Joint modeling of potential-field data and geodynamic interpretation for northeast Algeria
}

\author{
Benhenni L. ${ }^{1,2}$, Quesnel Y. ${ }^{3}$, Berguig M.C. ${ }^{1}$, Samai S. ${ }^{1}$, Hamoudi M. ${ }^{1,}$
}

${ }^{1}$ Université des Sciences et de la Technologie, Houari Boumediène, Algeria

2 Université de Djilali Bounaama, Khemis-Miliana, Algeria

${ }^{3}$ Aix-Marseille Univ., CNRS, IRD, INRA, Coll. France, CEREGE, Aix-en-Provence, France

*Corresponding author : M. Hamoudi, email address : hamoudi@usthb.dz

\begin{abstract}
:
The crustal structure beneath the northeastern continental part of Algeria is still largely unknown. Here we use potential field data processing, modeling and interpretation in order to investigate the deep sedimentary layers of this area and the transition with the basement. Indeed the gravimetric and magnetic field maps unveil the main geological domains of North Algeria: the AICaPeKa domain, the Tellian Nappes, the Atlas and the South-Atlasic Fault (SAF). Our modeling approach combines the prediction of gravimetric and magnetic field signals along $4 \mathrm{~N}-\mathrm{S}$ profiles that cross those domains and using constraints from seismic lines. The resulting cross-sections reveal the roots of the main E-W tectonic detachments of this area: the northern Suture Zone, the Tell Front, and the SAF. It seems that they are all initiated in the lower crust, nearby the continental/oceanic crustal transition for the Suture Zone, and several tenths of kilometers south from this transition for the Tell Front and the SAF detachments. Using these detachments, the lower parts of the crust are sometimes uplifted to only $5 \mathrm{~km}$ deep in the crust, while the upper crust is sometimes thickened to reach $15 \mathrm{~km}$ of thickness. Large magnetization and density contrasts are observed right beneath the Suture Zone.
\end{abstract}

\section{Highlights}

- Potential Field Data and North-eastern Algeria. Constrained Joint Geophysical Modeling and Crustal structure. Deep rooting crust of the Algerian Northern Suture Zone, the Tell front and the South Atlasic Fault. Large magnetization and density contrasts are observed right beneath the Suture Zone.

Keywords : Aeromagnetic field data, Gravity anomaly, Algeria, Modeling, Crust 


\section{Introduction}

Potential-field mapping allows to unveil buried geological structures. They are widely used for ore mining, gas and oil exploration, but they also help - depending on the measurement altitude - to investigate deeper structures like crustal fault zone, basement top depth, Moho depth, etc. (Dentith and Mudge, 2014). Most of the published studies dealing with the interpretation of potential-field maps in Northern Africa concerns the upper crust and mainly sedimentary basins (i.e. the first kilometer), with economic implications (e.g. Allek and Hamoudi, 2008; Boubaya et al., 2011). Seismic hazard characterization and evaluation also require such geophysical data (e.g. Ouyed et al., 2011; Samai et al., 2017). Indeed, the shore of Northeast Algeria is one of the most active tectonic region in the Mediterranean area. This active margin, corresponding to the boundary between the African and the Eurasian plates, induces many destructive earthquakes since several centuries (Benouar, 1994; Mokrane et al., 1994; Harbi, 2001; Harbi and Benhallou, 2006; Maouche et al., 2019; Bendaoud et al., 2019; Ousadou and Bezzeghoud, 2019). Most of these earthquakes were initiated in the Internal Zone. Therefore several geophysical surveys like the MARADJA and SPIRAL scientific programs investigated the margin unveiling its crustal structure. However, the continental areas - particularly the Tellian and Atlasic belts - were not so well studied, despite some attempts using surface geology (Frizon de Lamotte et al., 2000; Bracène and Frizon de Lamotte, 2002). Eventual seismic and well data are available but belong to mining and oil companies. Several studies such as Asfirane and Galdeano 
(1995), Idres (1983), Bournas et al. (2003), Abtout et al. (2014), Meliani et al. (2016) and Boukerbout et al. (2018) used gravity and magnetic data (with eventual further processing showing main buried fault directions, main source depths, etc.) to investigate deep crustal structure, but numerical modeling lacks. Therefore we mainly focus in this study on the potential-field data available for the corresponding NE Algeria area in order to constrain numerical models of the crust. The study's scale is regional (i.e. between local and country scale). After introducing the geological context and the geophysical data, the modeling method will be described. Then, the results of the modeling along 4 profiles will be shown and analysed in order to unveil eventual common crustal characteristics from W to $\mathrm{E}$ in this area.

Fig. 1. Geological context of the northeastern part of Algeria, modified from the geological map of Africa from Thiéblemont et al. (2016), and including information from Yelles et al. (2009), Medaouri et al. (2014) and Abacha (2015). $2 D$ crustal modeling was performed beneath the 4 green dashed profiles. Projection system is UTM Zone 31 with WGS84 ellipsoid. The onset on right bottom shows an extended view of the North Africa main geological regions and the western part of the Mediterranean Sea.

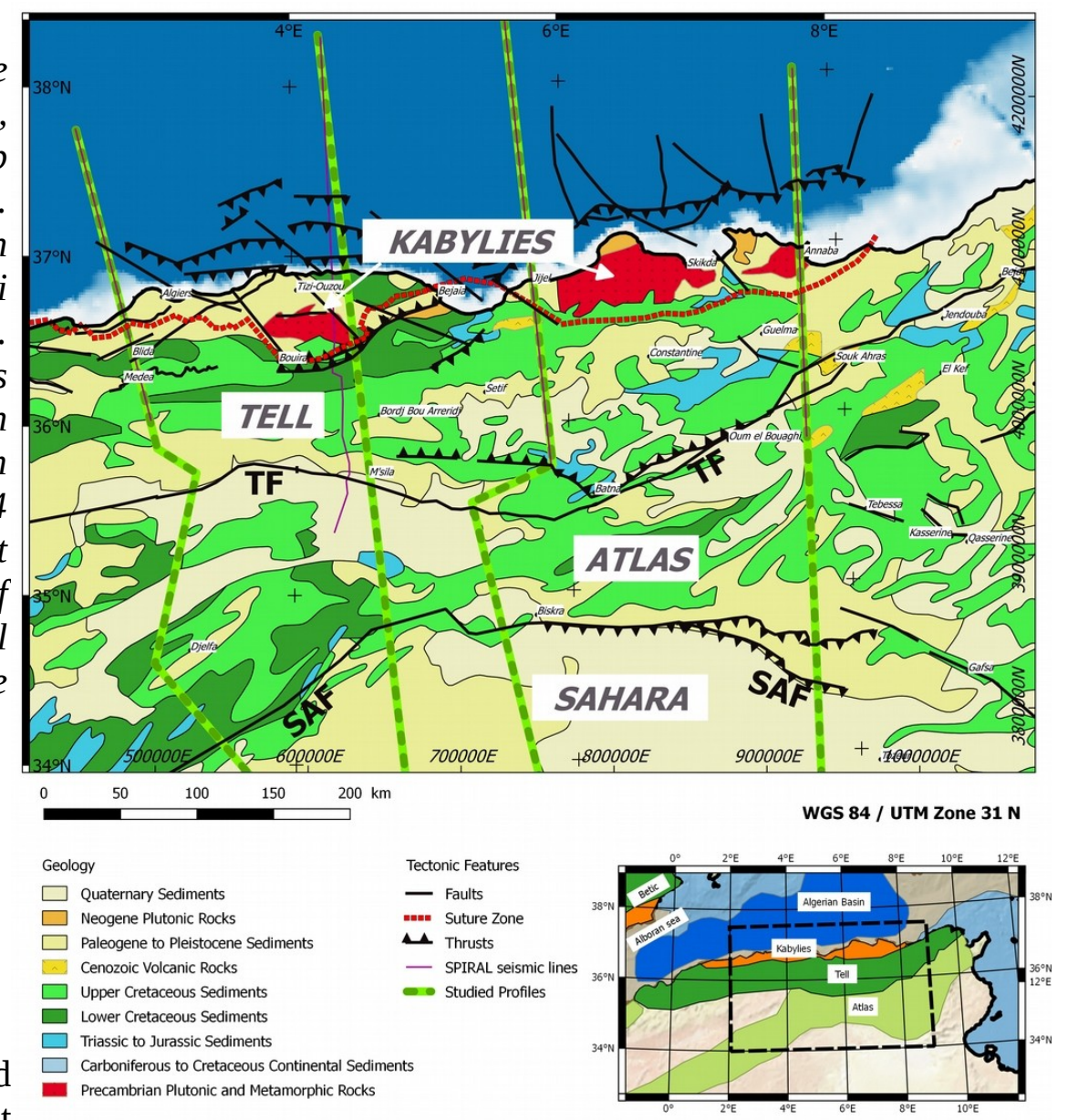

\section{Geological context}

The North of Algeria was affected by the alpine geodynamical event during Cenozoic: while the closing of the Tethyan Ocean occurred, the Algerian basin opened. During the Upper Cretaceous epoch (84 Ma), the opening of the Atlantic ocean led to the inversion of the African plate movement (Le Pichon and Gaulier, 1988; Dewey et al., 1989; Roest and Srivastava, 1991; Stampfli et al., 1991; Dercourt et al., 1993; Mauffret et al., 2004), which formed the Pyrénées and Alps mountain belts (ECORS Pyrenees Team, 1988; Roure et al., 1989; Choukroune et al., 1990; Nicolas et al., 1990). The Algerian back-arc basin started to be opened during Oligocene (Fig. 1), but the slab breaking led to the carriage of some crustal blocks from the European plate over the northern parts of the African plate (Cherchi and Montadert, 1982; Burrus, 1984; Casula et al., 2001): this zone is now called « AlKaPeCa " for Alboran, Kabylies, Péloritain and Calabre (Bouillin, 1986). In northern Africa between the " kabylides » and the African margin, an accretion prism (flyschs units) developed synchronously to the 
total opening of the Algerian basin 13 Ma ago (Frizon de Lamotte et al., 2000; Mauffret et al., 2004). More recently, the convergence between Africa and Europe built the Tellian Atlas belt (Meghraoui et al., 1986) which typically shows E-W detachment (thrust) faults affecting the Alboran Sea and the Maghrébides landscapes (Meghraoui et al., 1986; Meghraoui and Doumaz, 1996; Boudiaf et al., 1999).

Our study area concerns the northeastern parts of Algeria, in the Tertiary Alpine belt (Durand-Delga, 1969), extending from $3^{\circ} \mathrm{E}$ to $\sim 10^{\circ} \mathrm{E}$ at the Algeria/Tunisia border, and from the Mediterranean Sea in the north to the $34^{\circ} \mathrm{N}$ latitude, i.e. to the south bordered by the well-known geological structure called the South-Atlasic Fault (SAF) zone (Fig. 1). From North to South in this area, we can distinguish two main geological domains: in the North, the Tellian Atlas with the Kabylides, the Flyschs and Tellian units; in the south, the Saharan Atlas. A major tectonic contact, the Tellian Fault zone, separates these domains. The Tellian Atlas is composed by an internal domain (Kabylides belonging to AlKaPeCa), Flysch units and an external domain (the Tellian nappes). The internal domain corresponds to a Hercynian crystalline and Precambrian metamorphic basement with gneiss, marble, amphibolites, mica schists and schists, covered by Paleozoic sediments (Bouillin, 1986). The Great and Lesser Kabylies are the most representative outcrops of the crystalline basement, while tectonic flakes affect the carbonate sediments coverage (Raoult, 1975). The flysch units are detrital materials overlapping the Tellian units of the external domain. The latter corresponds to allochthonous and para-autochthonous marl and limestone units (Durand-Delga, 1969; Bouillin, 1986). These units comprise the southern margin of the old Tethys (Frizon de Lamotte et al., 2006). The Saharan system is an intra-continental Cenozoic belt that moved Mesozoic sedimentary rocks (Mattauer et al., 1977), characterized by 2 NESW anticlinal axes. It overlaps the Saharan Precambrian platform to the south in the SAF zone (Frizon de Lamotte et al., 2000). Despite numerous geological studies of basement outcrops in Algeria, it is clear that we lack of geophysical images under the sedimentary coverage. Therefore this study aims at using potential field data to unveil the basement properties and structure in NE Algeria.

\section{Geophysical constraints}

\subsection{Gravimetric data}

Despite great efforts developed by geological institution, oil and mining companies since more than a century, geophysical data cover very sparsely the territory. Many local or regional studies have been conducted, especially its northern part (Lagrula, 1951; Idres, 1983; Boudella, 1989; Zerdazi, 1990; Idres et al., 1996, 1998; Samai, 2007). Even though, ground measurements are not always available. In this study, a grid of the gravity anomaly field derived from the spherical harmonic Earth Gravity Model EGM08 (Pavlis et al., 2012) was used. This model was built using the GRACE satellite measurements. The free-air anomaly was extracted in a grid of $3.7 \mathrm{~km}$ spatial resolution. Then, using the ETOPO1 model (Amante and Eakins, 2009), the FA2BOUG algorithm of Fullea et al. (2008) was applied to compute the Bouguer anomaly grid, considering a 2.67 average crustal density. The resulting map is shown in Fig. 2. It reveals 4 main domains of gravity signal. First, a maximum positive (up to 200 mGal) signal is observed, as expected, along the whole north coast, corresponding to the uplift of the mantle at the continental/oceanic crustal transition. The effect of the basement nappes in the internal zone does not influence this general signal. South to this first area, a second zone of large negative (< $-100 \mathrm{mGal}$ ) anomalies seems to correlate with the Tellian Fault zone and the eastern part of the basin between this fault and the SAF zone. Similar anomalies are observed in a third region southwest of the study area. These negative anomalies may correspond to a local thickening (by thrusting faults?) of the sedimentary basin between the Tellian Fault and the SAF zones, but this issue will be addressed later. 
Between these 2 zones of negative anomalies, a less negative (about $-60 \mathrm{mGal}$ ) signal is observed over a NW-SE dextral sliding zone. Then, south to the SAF zone, a fourth ensemble with weak negative ( -60 to $-30 \mathrm{mGal}$ ) anomalies is observed. It corresponds to the extension of the Central Hoggar, covered by a thin $(<1-2 \mathrm{~km})$ sedimentary layer.

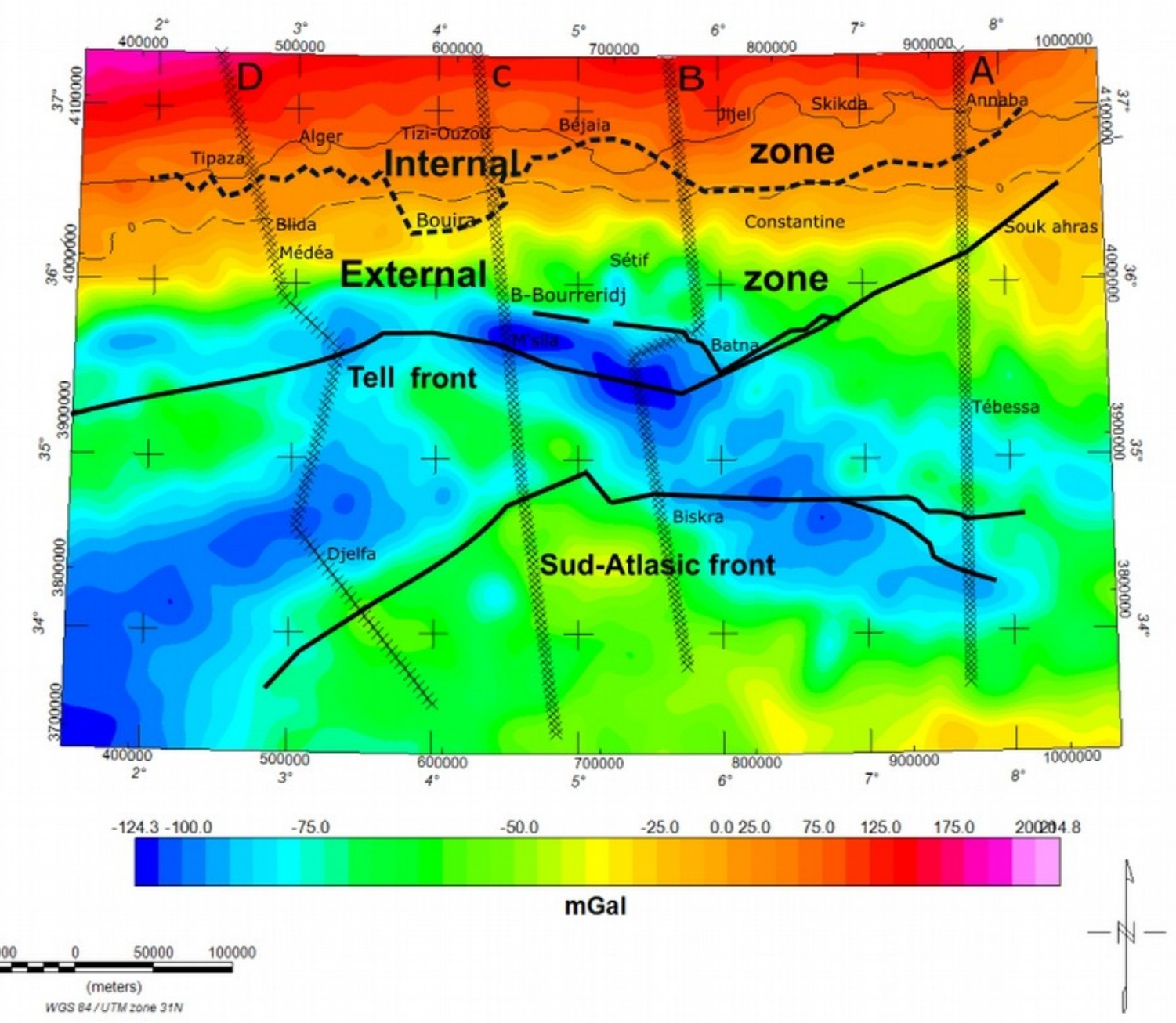

Fig. 2. Bouguer gravity map of the studied area in NE Algeria. The modeled profiles are indicated by cross-dashed lines, while the main faults and geological contacts correspond to solid and dashed lines. Projection system is UTM Zone 31 with WGS84 ellipsoid.

\subsection{Magnetic field data}

\subsubsection{Aeromagnetic field map}

Our dataset corresponds to a part of the aeromagnetic survey performed in the seventies by the North American AeroService Co private company for the benefit of SONATRACH and SONAREM Algerian 
oil and mining companies. The total intensity of the magnetic field was sampled every $46 \mathrm{~m}$ along the 2 $\mathrm{km}$ spaced flight lines and $10 \mathrm{~km}$ tie-lines spacing. The survey was flown at $150 \mathrm{~m}$ ground clearance and NO-SE flight lines direction. The final grid has a $2 \mathrm{~km}$ spatial resolution. Fig. 3a shows the magnetic field anomaly map over the studied area, revealing a long wavelength global north-south dipolar shape as expected at the given location and associated magnetic dip. If we analyze in detail the short wavelength magnetic anomaly distribution, one can notice 3 main entities. Along the northern coast of Algeria, large positive anomalies are observed over the active margin. In details, they unveil the plutonic and metamorphic internal zones of the Great and Lesser Kabylies, as well as the region of Annaba including Edough Massif. The second domain corresponds to the southern part of the Tellian Atlas, where SW-NE negative anomalies are observed. This negative zone is more extended towards East and turns to E-W in direction. The most negative part seems to correspond to the SAF zone. The last domain is located in the northwestern part of the studied area, where several isolated magnetic anomalies are observed, corresponding to Paleogene and Cretaceous deposits. Lastly, an intense circular anomaly is located SE of Djelfa area $\left(3.6^{\circ} \mathrm{E}, 34,0^{\circ} \mathrm{N}\right)$ : it may correspond to a magmatic intrusion.

Fig. 3. a) Aeromagnetic TF anomaly map of the studied area in NE Algeria. Same symbols as for Fig. 2. Projection system is UTM Zone 31 with WGS84 ellipsoid; b) Reduced-to-pole aeromagnetic TF anomaly map of the studied area in NE Algeria. Same symbols as for Fig. 2. Projection system is UTM Zone 31 with WGS84 ellipsoid.

\subsubsection{Aeromagnetic field map reduced to the pole}

The map of the magnetic field has been reduced to the pole using the Fourier transform (Baranov, 1957) inclination and declination values of $50^{\circ}$ and $0^{\circ}$ respectively (Asfirane and Galdeano, 1995). In order to better describe the magnetic field map, and as this map contains a large variation in inclination, we applied the reduced to the differential pole. The resulting map in Fig. 3b shows a better structural's axes localization of the region. Indeed the South Atlasic Flexure is then well defined along the 0 curve, caused by a strong contrast of magnetization between the Precambrian base of the Saharan platform and the Tell units. The Tell itself is less visible due to weaker $(b)$
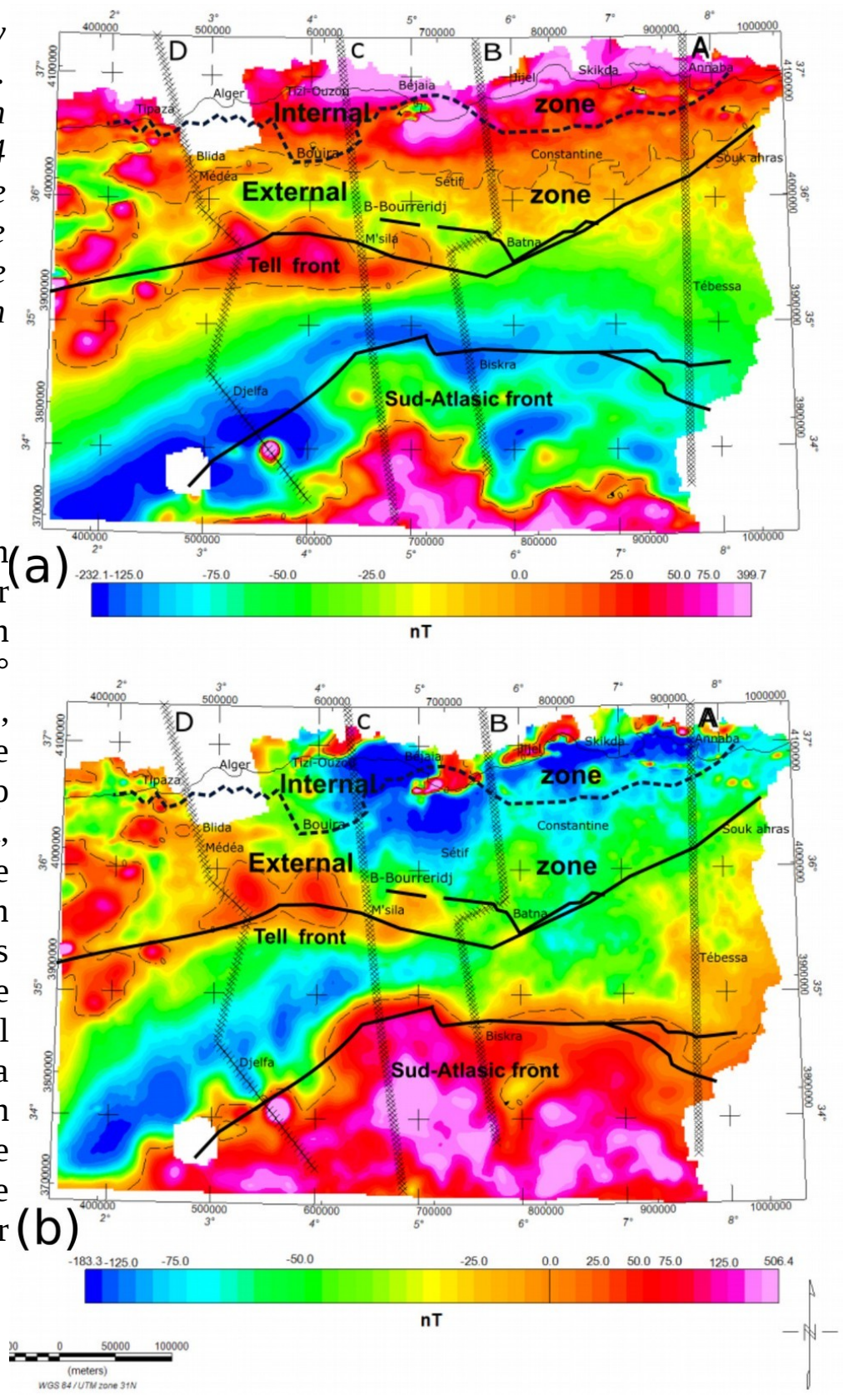
contrasts of magnetization. We also observe a correlation between some positive anomalies and the location of the northern Algerian volcanism, particularly nearby Bejaia.

\subsection{Other constraints}

Information from the last version of the geological map of Africa were used to constrain the outcropping geological units (Thiéblemont et al., 2016), while the topography of our studied area was set by the ETOPO1 model (Amante and Eakins, 2009). Additionally, a number of SPIRAL interpreted seismic cross-sections were used, in particular for the continent/ocean crustal transition (Leprêtre et al., 2013; Mihoubi et al., 2014; Bouyahiaoui et al., 2014; Aïdi et al., 2018). However, the southern extension of these seismic data is not sufficient to constrain the crustal structure of our area. Therefore the CRUST2.0 global tomography model was considered to constrain the Moho depth and the crustal layers' thicknesses (Bassin et al., 2000). Its crude spatial resolution $\left(2^{\circ} \times 2^{\circ}\right.$ grid) does not allow getting details about the regional topography variations of the crustal interfaces, but at least it gives a reasonable starting model.

\section{Modeling method}

Geological modeling using potential-field data is a non-unique solution problem. The forward approach to solve for this consists in building a crustal model with one or several blocks of homogeneous density and magnetic property (susceptibility and remanent magnetization) values (Blakely, 1995) which will influence the predicted gravity and magnetic field anomaly signal. The susceptibility $\mathrm{K}$, strictly positive, relies on the iron oxide content and grain size in rocks and ranges generally from $10^{-6}$ to $10^{-1}$ SI. Rock densities $\rho$ vary in a smaller range, typically between $1500 \mathrm{~kg} / \mathrm{m}^{3}$ (unconsolidated sediments) to $3300 \mathrm{~kg} / \mathrm{m}^{3}$ (mantle rocks). Standard values of K and $\rho$ for crustal rocks can be found in Dentith and Mudge (2014) and were used in our models. By trial-and-errors in terms of physical parameters and layer geometries, the resulting model should predict as much as possible the data (i.e. minimizing the RMS residuals). In the presence of a certain number of constraints or prior informations like (1), the geometry of the geological layers derived from seismic cross-sections, (2), laboratory measurements of the physical parameters of geological samples (well data), or in the case of very simple models (i.e. geometrically-speaking), an inverse method can be used to mathematically adjust the topography and/or depth of each crustal interface. In our case, for the continental parts of Algeria, we are limited to the detailed potential-field data and to the low-resolution CRUST2.0 data to constrain the crustal structure. Therefore a forward approach was used along $4 \mathrm{~N}-\mathrm{S}$ profiles which extend the SPIRAL seismic lines towards South. The Oasis montaj commercial software and its GM-SYS 2D modeling module were used (Geosoft Inc., 2017). Detailed descriptions of the modeling approach are mentioned in Grant and West (1965), Telford et al. (1990) and Blakely (1995). Here we used the following steps: (1) defining the profile as a southern extension of a SPIRAL seismic cross-section; (2) building a starting crustal model using information from this SPIRAL cross-section and the CRUST2.0 data, (3) setting standard values of crustal density for each layer (Table 1), (4) slightly adjusting these values and/or the geometry of each layer in order to better fit the gravimetric observations along the profile, (5) setting standard values of magnetic susceptibilities for each layer. The parameters of the magnetic inducing field are derived thanks to the IGRF field for the 1980 epoch (Finlay et al., 2010; Thébault et al., 2015) (see Table 1), (6) slightly adjusting those susceptibility values to better fit the magnetic field data, and (7) possibly splitting some 'apparently-homogeneous' layers in several blocks with different magnetic susceptibilities. No remanent magnetization was added to our layers, in the absence of available data concerning this parameter at depths in Algeria. One has to keep in mind that 
mathematically-speaking, the predicted signal is different than the observed one. Indeed the computed anomaly field is really the effect of the causative bodies. This does not hold true for the total field magnetic anomaly distribution (data) which is in fact the projection on the reference field. Depending on the angle between magnetization vector and the core field vector, the error may be large. At our considered dip latitude the error is however relatively small and may be neglected. Lastly, in the modeling, the observed magnetic field is the original TF anomaly distribution with its actual magnetization distribution. It cannot be the reduced-to-pole magnetic anomaly for which the magnetization and the inducing field are both vertical.

Table 1: initial (standard) rock properties given to each lithological block in the model

\begin{tabular}{lcc}
\hline Geological blocks & Density $\left(\mathrm{g} / \mathrm{cm}^{3}\right)$ & Magnetic Susceptibility (SI) \\
\hline Sedimentary cover (continent) & $2.2-2.4$ & 0.001 \\
Sedimentary cover (ocean) & 2.1 & 0.0001 \\
Oceanic Crust & 2.9 & 0.1 \\
Upper Crust & 2.67 & 0.01 \\
Lower Crust & 2.8 & 0.01 \\
Mantle & 3.3 & 0 \\
\hline
\end{tabular}

\section{Results}

Final N-S cross-sections are shown and described from East to West.

\subsection{Profile A (South of Annaba)}

This $380 \mathrm{~km}$ long profile extends a SPIRAL seismic cross-section performed in the margin north of Annaba (Bouyahiaoui et al., 2014), and ends south of Tebessa area. Fig. 4 shows the resulting crosssection after modeling, revealing that the lower crust reduces its thickness $(<10 \mathrm{~km})$ towards north but increases its average magnetic susceptibility (up to more than $0.01 \mathrm{SI}$ ). The upper crust seems to show more magnetization contrasts within a stable $10 \mathrm{~km}$ thickness. These contrasts are probably associated to the main detachment faults like (1) the internal/external suture zones with a 60 to $30^{\circ}$ dip, (2) the crustal root of the Tell Front, (3) and the root of the thrusting SAF over the Saharan platform. The Moho depth reaches $30 \mathrm{~km}$ beneath the Tell Front, and decreases to $20 \mathrm{~km}$ beneath the Saharan Platform. The model also reveals the thickening of the sedimentary layers at the two fronts (Tell and $\mathrm{SAF}$ ) and its thinning in the Internal Zone. 


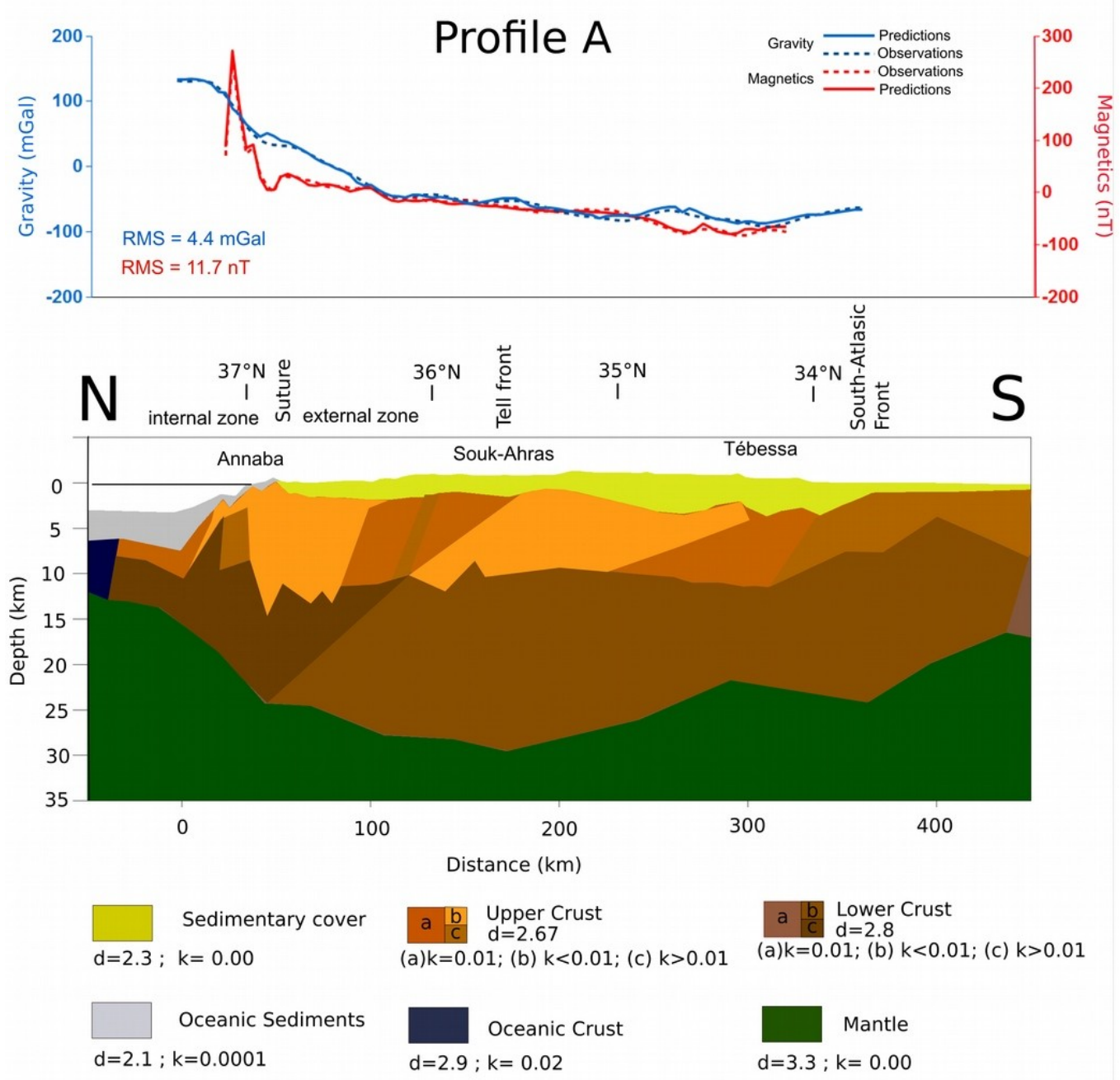

Fig. 4. Final modeled cross-section beneath profile A. Top: comparison between predictions (solid lines) and observations (dashed lines) of gravimetric (blue) and magnetic field (red) signals. Bottom: resulting geophysical cross-section with legend at bottom. Parameters of each block are d, density (in $\left.\mathrm{kg} / \mathrm{m}^{3}\right)$ and $\mathrm{k}$, magnetic susceptibility (SI).

\subsection{Profile B (Lesser Kabylies-Biskra)}

This N-S profile is offset towards West in the Batna region in order to cross the main magnetic anomalies south of Batna. Again, the first $100 \mathrm{~km}$ of this line coincides with a SPIRAL seismic crosssection (Mihoubi et al., 2014). Fig. 5 shows the final model, unveiling a magnetized (K > 0.01 SI) crust in the north. The edges of some crustal blocks with different susceptibilities are correlated with the crustal roots of the Tell Front and the SAF. These zones reach surface through sediments, where their inclination largely decreases to appear quasi-horizontal as detachment faults. These ramps lead to the thickening of the sedimentary basin between Biskra and Batna. Except the Moho depth variations, this model is similar to the adjacent one computed beneath profile A. 


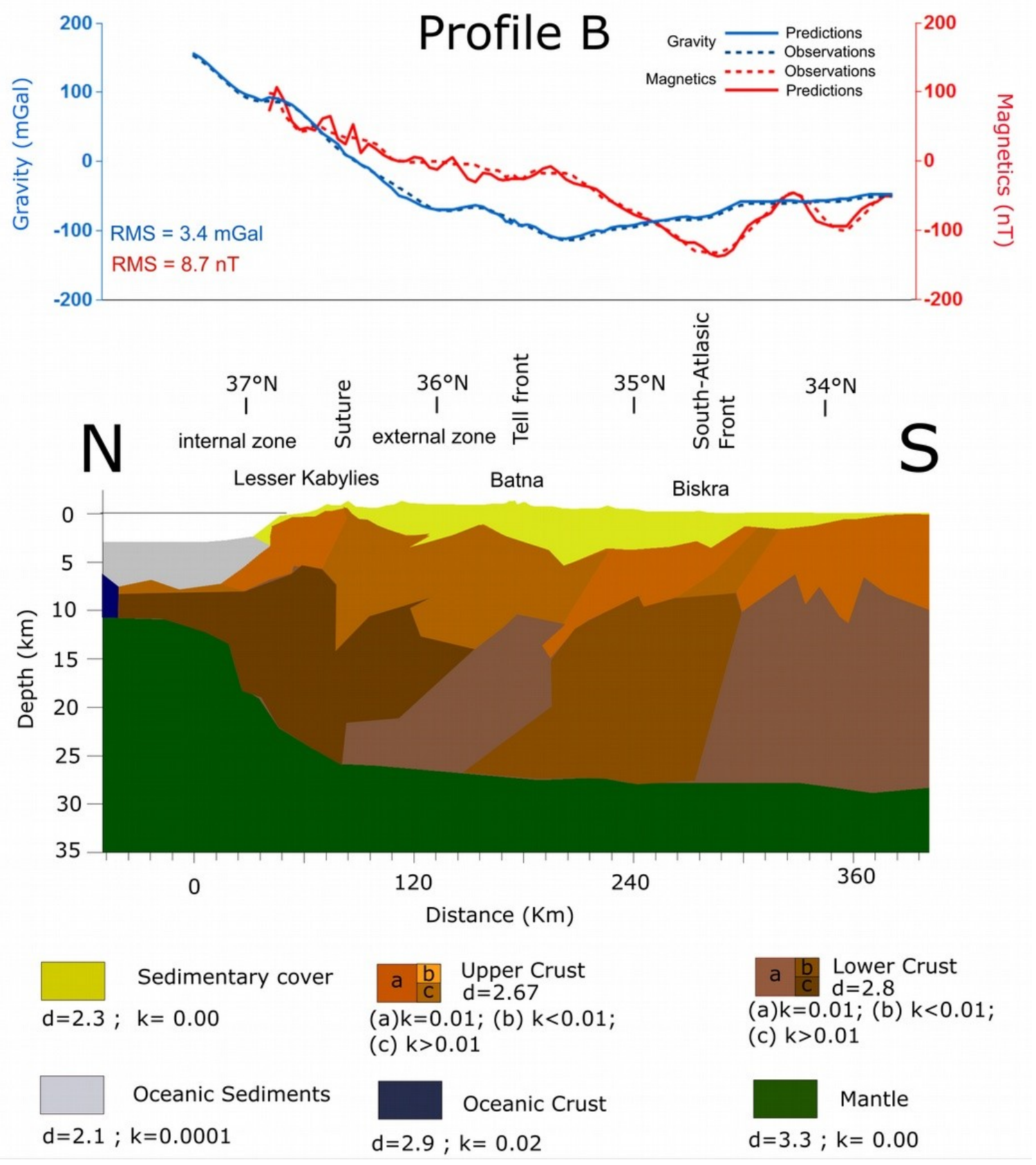

Fig. 5. Final modeled cross-section beneath profile B (same format as for Fig. 4).

\subsection{Profile C (Great Kabylies- M'Sila)}

This $400 \mathrm{~km}$ long profile starts in the margin north to Tizi-Ouzou, in Great Kabylies, to cross the Lesser Kabylies and M'Sila region to the south, down to the Saharan Platform. It corresponds to the extension of a SPIRAL seismic line in the Kabylia margin (Aïdi et al., 2018). The final model is shown in Fig. 6. It reveals that the Internal Zone crustal formations are here denser $\left(2.8 \mathrm{~g} / \mathrm{cm}^{3}\right)$ than the standard upper crust $\left(2.67 \mathrm{~g} / \mathrm{cm}^{3}\right)$. It seems that the crustal roots of the main detachment faults favoured both the overlapping of lower crust layers over upper crustal blocks of this Internal Zone, and the thickening of the sedimentary basin. 

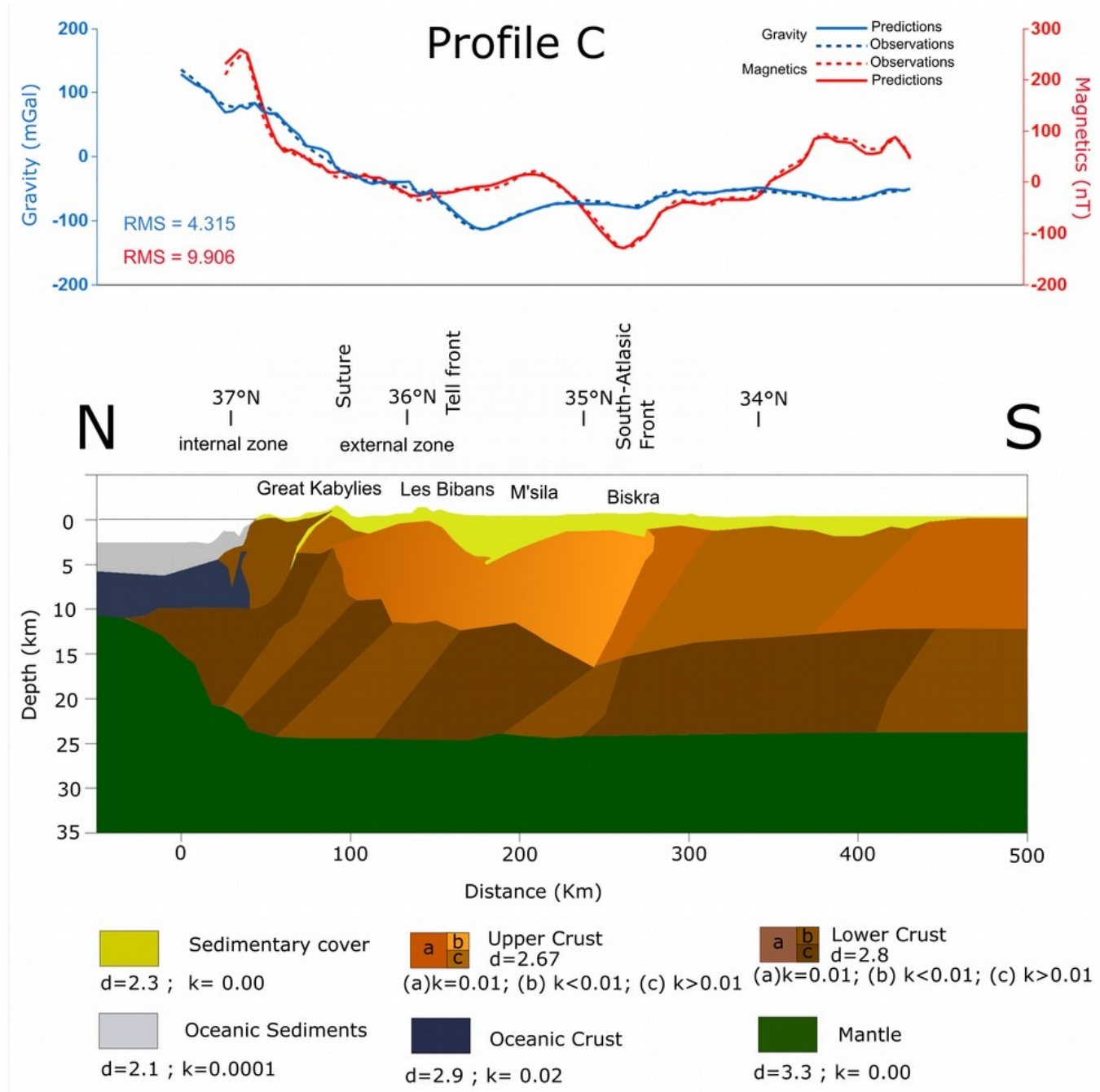

Fig. 6. Final modeled cross-section beneath profile $C$ (same format as for Fig. 4).

\subsection{Profile D (Tipasa-Djelfa)}

This western profile links Tipasa to Djelfa in the south, with a NNW-SSE general orientation. Leprêtre et al. (2013) published the interpretation of the SPIRAL seismic experiment in the margin. Our model shows that the Internal Zone layers are here less dense and magnetized than in the previous models (Fig. 7). However, the upper crust still shows a number of susceptibility contrast, again interpreted as the roots of the main detachment faults in the area. The source of the isolated magnetic anomalies south to the SAF may correspond to sharp susceptibility contrasts in the lower crust. Lastly, one should note that, following the interpreted seismic cross-section, the dip of the ocean-continent crustal transition is approximately constant and relatively weak $\left(<10^{\circ}\right)$ towards south, which is different than for the previous models. 


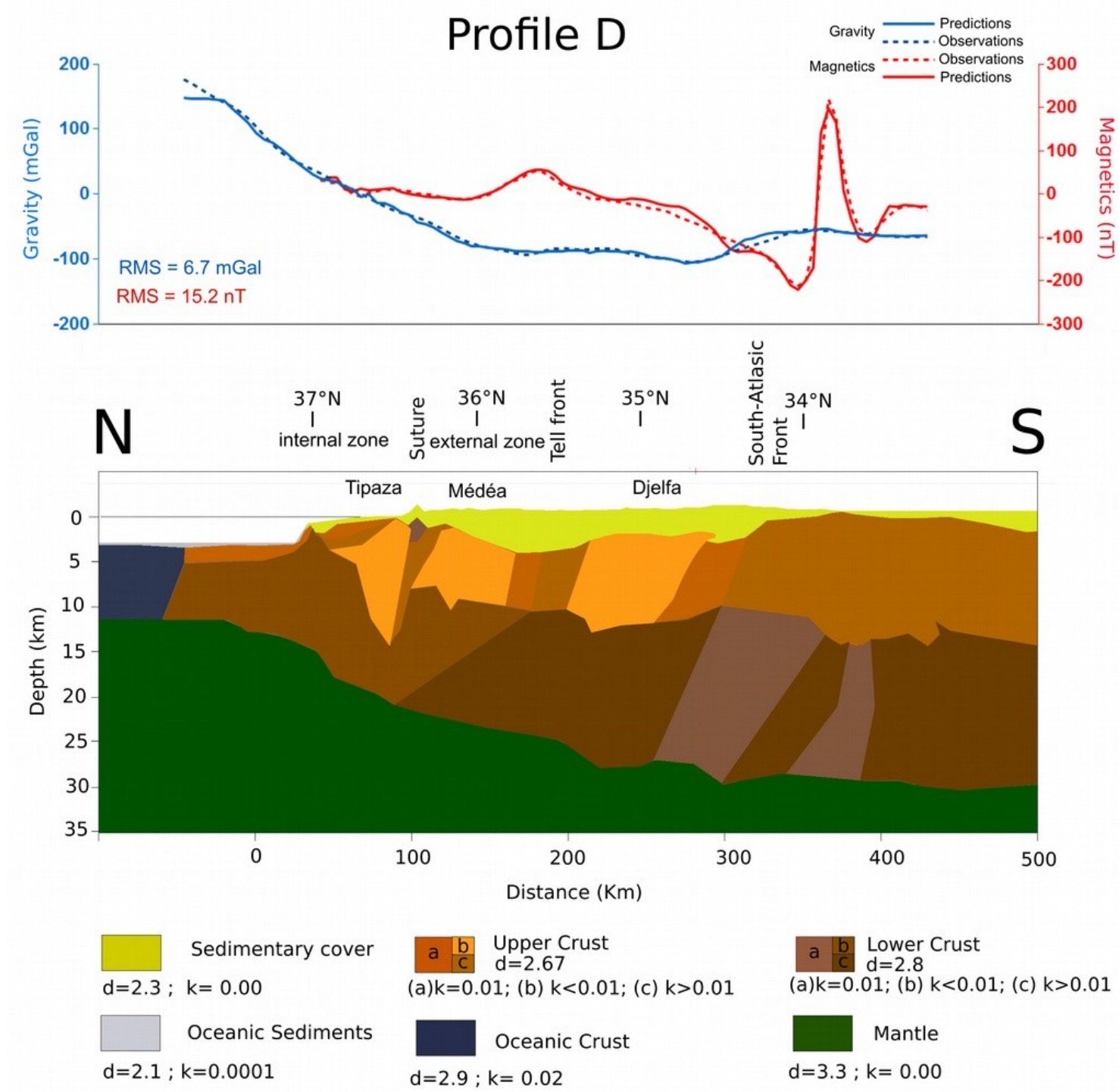

Fig. 7. Final modeled cross-section beneath profile D (same format as for Fig. 4).

\section{Discussion}

In Fig. 8, a schematic cross-section summarizes the main features resulting from the modeling along the 4 profiles. It unveils the main topographical variations of the interfaces between sediments, upper crust, lower crust and mantle. One of the major features corresponds to the thickening of the lower crust that overlaps the upper crust through the roots of the main detachment faults in this area. Beneath the Suture Zone, the top of the lower crust can reach 5-6 km of depth, while several kilometers to the south, the opposite is observed with a thicker upper crust. This area also corresponds to a significant density and susceptibility contrast. An overall common property is that, if these density and susceptibility contrasts within crustal layers really correspond to buried fault zones, then their dip is significant in the crustal blocks (about $40^{\circ}$ ) and weak at the crustal interfaces (about $10^{\circ}$ ). Towards south, the sedimentary basin becomes thin $(<4 \mathrm{~km})$, and the lower crust seems to be thicker than the 
upper crust. Such behaviors have to be confirmed by continental seismic lines in future studies, but at least it fits other crustal models of the North Africa's active margin (Seber et al., 2001; Zeyen et al., 2005; Ebinger et al., 2017). For instance, Zeyen et al. (2005) introduced a numerical model of the crust and lithosphere between Spain and Morocco with no real apparent crustal thickening and/or thrusting on the continental parts. With similar crustal density values, this large-scale study was not able to solve for the influence of the roots of the main thrusts in Morocco on the gravity and magnetic field data. Ayarza et al. (2005), through gravity data modeling, showed some crustal thickening caused by dipping crustal-scale thrust faults, sometimes leading to Moho offsets. Besides, such studies - mainly restricted to the western part of North Africa - also suggest that the unusual High Atlas topography is also caused by a thin lithosphere and an eventual warm mantle upwelling (Ebinger et al., 2017).

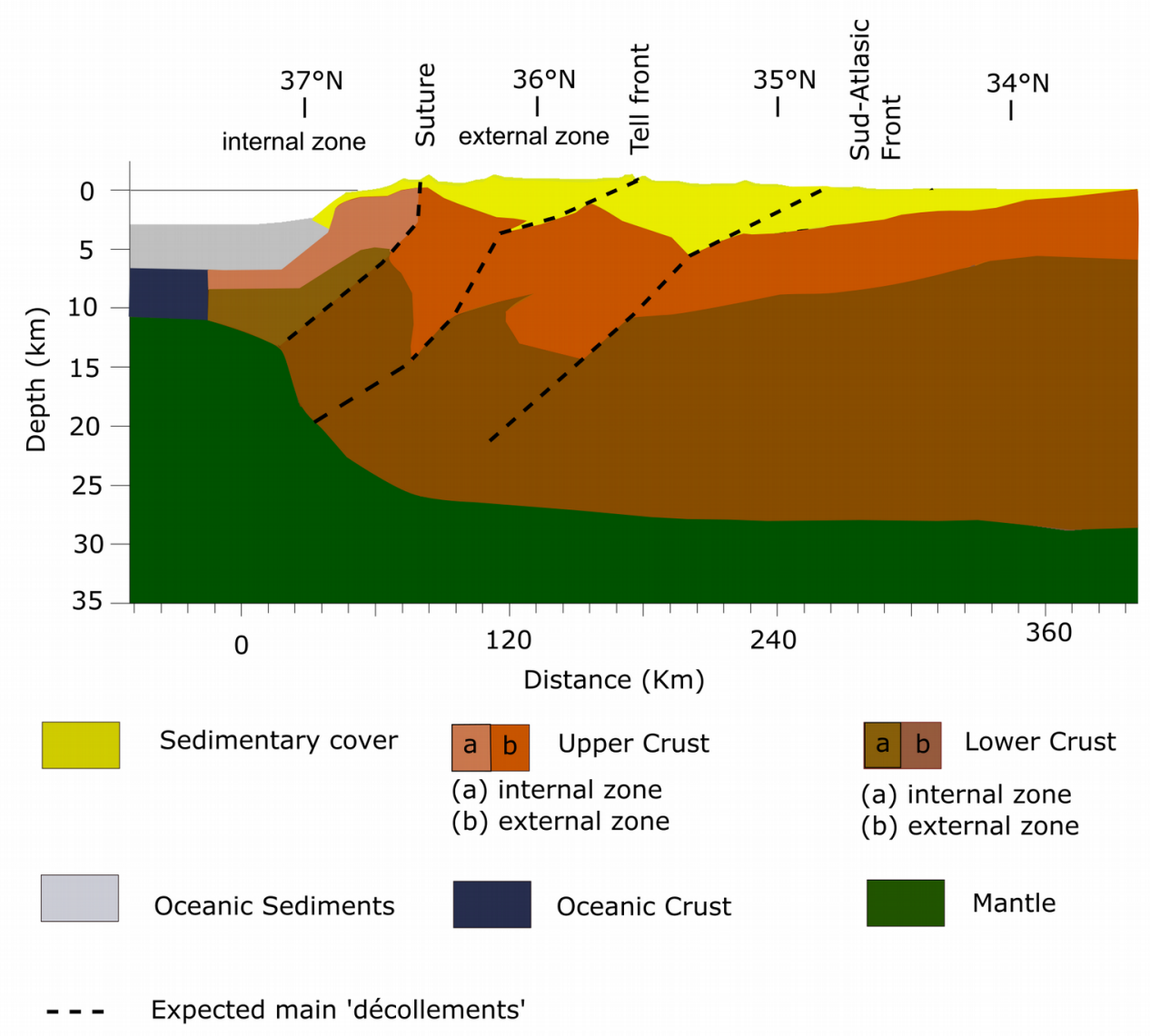

Fig. 8. Synthetic cross-section with main features modeled in the 4 previous profiles. 
Our model may suffer from the separation of the crust into 2 layers only: the upper part and the lower part with 2.67 and $2.8 \mathrm{~g} / \mathrm{cm}^{3}$ density values, respectively. A better approach would be to consider a density gradient distribution varying from 2.6 to $2.9 \mathrm{~g} / \mathrm{cm}^{3}$ within the entire crust (Zeyen et al., 2005). Therefore another model was tested for profile B using a middle crustal layer with density of 2.74 $\mathrm{g} / \mathrm{cm}^{3}$ (Fig. 9). The RMS residual value is larger than for the 2-layer crustal model, but it is still acceptable. This intermediate layer has a variable thickness from 2 to $10 \mathrm{~km}$ throughout the crosssection, because it may be largely affected by the main detachment faults (e.g. the root of the SAF). Then our 2-layer model does not seem to be far from a certain geological reality.

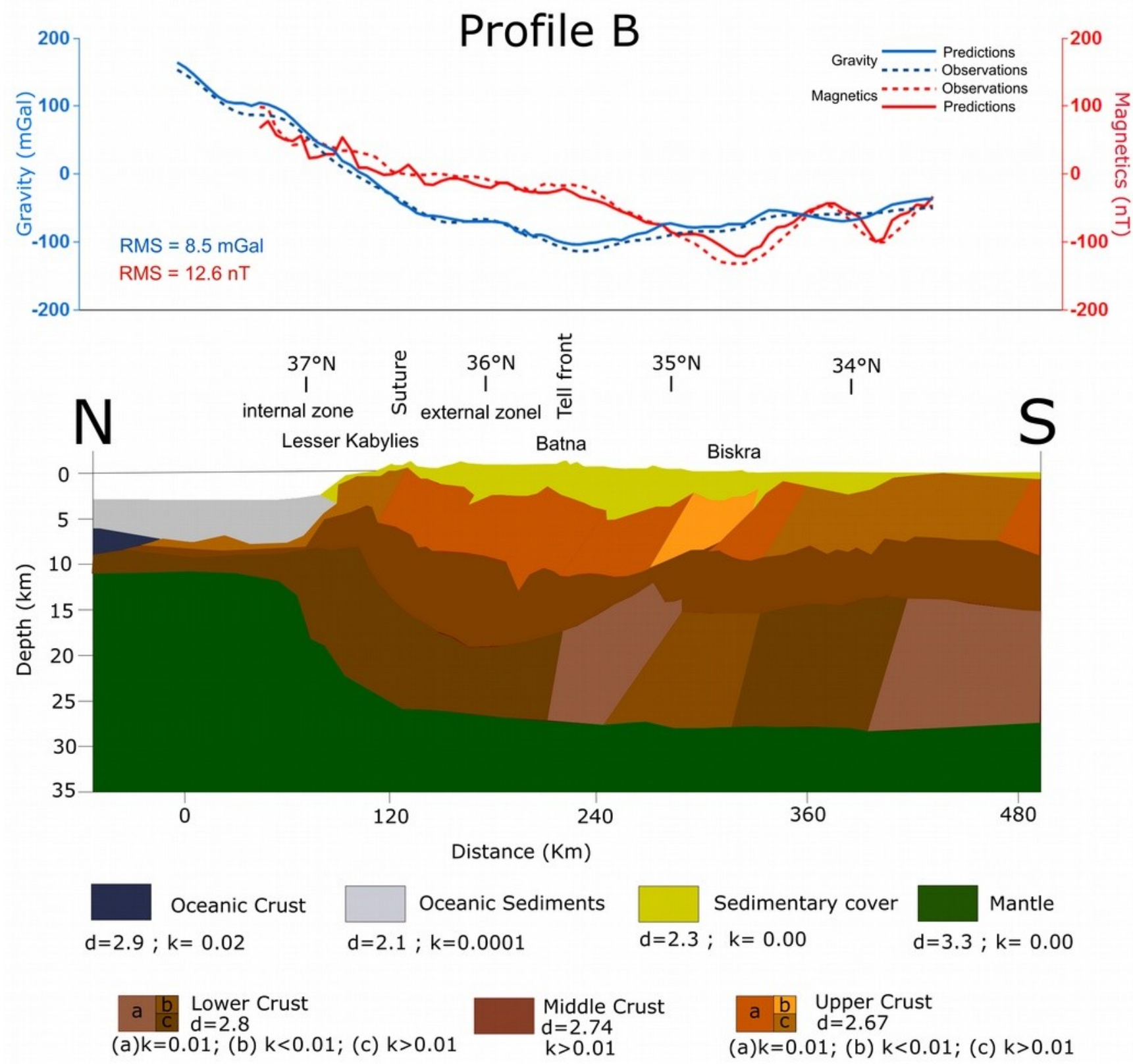

Fig. 9. Same as Fig. 4 for profile B, but starting with 3 crustal layers (upper, middle and lower). 
In order to fit the magnetic field anomaly signal, one can adjust together magnetic susceptibility (and remanence if considered) and thickness of crustal blocks. We investigated these parameters in the modeling of the lower crust beneath profile A (Fig. 10). Indeed we constrained the maximum thickness of this layer to $10 \mathrm{~km}$, for a magnetic susceptibility greater than $0.01 \mathrm{SI}$. The other layers have the same properties than in the previous model of Fig. 4. Again, the RMS residuals are slightly larger than for the previous model, showing the reasonability of the thickness-to-susceptibility ratio in those primary models. Concerning the effect of eventual remanence, in the absence of magnetization measurements on samples from cores of deep drillings, one cannot really investigate it. A recent study has however shown that it should be taken into account in the middle and lower crusts (Launay et al., 2017, 2018).

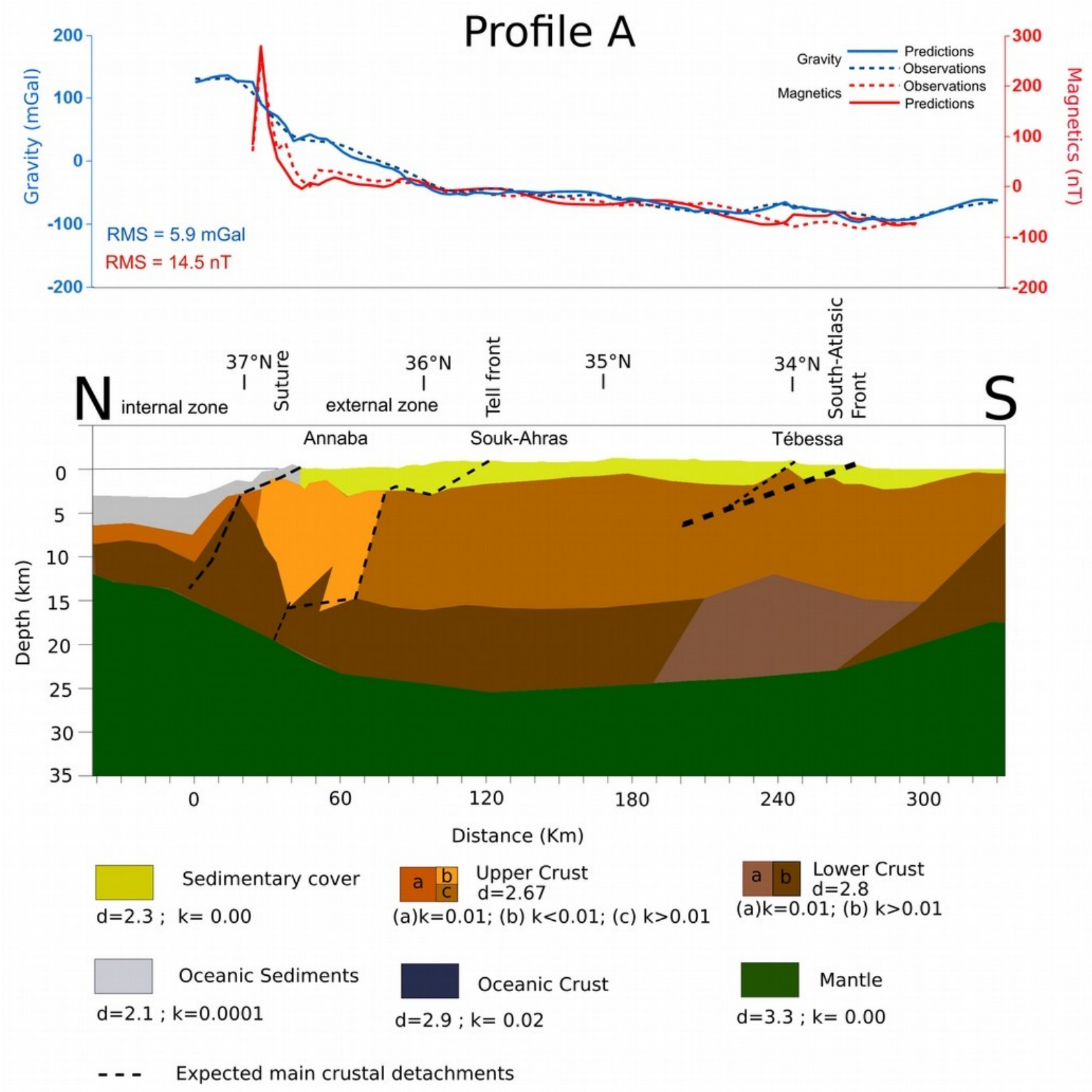

Fig. 10. Same as Fig. 4, but considering a thinner lower crust with a larger magnetic susceptibility. 


\section{Conclusions}

Thanks to a forward modeling approach to investigate the deep crustal structures beneath NE Algeria, we were able to fit both gravity and magnetic field data. Our 2D models along $4 \mathrm{~N}-\mathrm{S}$ profiles show continuity between geological interpretations of seismic lines nearby the Mediterranean margin and the roots of the main detachment fault zones that separate this area at the surface: the Internal/External Suture Zone, the Tell Front and the South Atlasic Fault zone. Indeed, the modeled density and susceptibility contrasts clearly correspond to these fault zones at depth. They seem to originate nearby (Suture Zone) or several tenths of kilometers south to (Tell Front and SAF) the continental/oceanic crustal transition, but they also induce sharp topographical variations of the crustal interfaces (i.e. variation of crustal layer thickness). In the sedimentary basin, they are flattened and serve as 'thrusting ramps', probably favoured by the presence of Triassic formations at the base. Beneath the External/Internal Suture Zone, significant contrasts of density and magnetic susceptibility are also systematically observed.

Of course, one of the implications of our study is that reflection and refraction seismic data are clearly needed to better image the continental crust beneath the sedimentary basin in NE Algeria. Indeed we should not forgive that such crustal contrasts are good candidates for well-mineralized zones, with a probable non-negligible economic potential.

\section{Acknowledgments}

Warm thanks to Eric Ferré and the anonymous reviewer for their comments which helped greatly in improving the quality of the manuscript. We also acknowledge the Editor for his comments. We are grateful to the Bureau Gravimetrique International (BGI) for providing us gravity data.

\section{References}

Abacha, I., 2015. Étude de la sismicité de la région Nord-Est de l'Algérie. PhD Thesis. Science Faculty, Univ. Ferhat Abbas-Setif, Algeria 236pp.

Abtout, A., Boukerbout, H., Gibert, D., 2014. Gravimetric evidences of active faults and underground structure of the Chlef seismogenic basin (Algeria). J. Afr. Earth Sci. 99 (2), 363-373. https://doi.org/10.1016/j.jafrearsci.2014.02.011.

Aïdi, C., Beslier, M.-O., Yelles-Chaouche, A.-K., Klingelhoefer, F., Bracene, R., Galve, A., Bounif, A., Schenini, L., Hamai, L., Schnurle, P., Djellit, H., Sage, F., Charvis, P., Déverchère, J., 2018. Deep structure of the continental margin and basin off Greater Kabylia, Algeria - new insights from wideangle seismic data modeling and multi-channel seismic interpretation. Tectonophysics 728-729, 1-22. https://doi.org/10.1016/j.tecto.2018.01.007.

Allek, K., Hamoudi, M., 2008. Regional-scale aeromagnetic survey of the south-west of Algeria: a tool for area selection for diamont exploration. J. Afr. Earth Sci. 50, 67-78. https://doi.org/10.1016/j.jafrearsci.2007.09.018. 
Amante, C., Eakins, B.W., 2009. ETOPO1 1 arc-minute global relief model: procedures, data sources and analysis. NOAA Tech. Memo. NESDIS NGDC-24, 19pp.

Asfirane, F., Galdeano, A., 1995. The aeromagnetic map of northern Algeria: processing and interpretation. Earth Planet. Sci. Lett. 136, 61-88. https://doi.org/10.1016/0012-821X(95)00043-4.

Ayarza, P., Alvarez-Lobato, F., Teixell, A., Arboleya, M.L., Tesón, E., Julivert, M., Charroud, M., 2005. Crustal structure under the central High Atlas Mountains (Morocco) from geological and gravity data. Tectonophysics 400 (1-4), 67-84. https://doi.org/10.1016/j.tecto.2005.02.009.

Baranov, V., 1957. A new method for interpretation of aeromagnetic maps: pseudogravimetric anomalies. Geophysics 22 (2), 359-382. https://doi.org/10.1190/1.1438369.

Bassin, C., Laske, G., Masters, G., 2000. The current limits of resolution for surface wave tomography in north America. EOS Trans. AGU 81, F897.

Bendaoud, A., Hamimi, Z., Hamoudi, M., Djemai, S., Zoheir, B., 2019. The Geology of the Arab World-An Overview. https://doi.org/10.1007/978-3-319-96794-3.

Benouar, D., 1994. Materials for the investigation of the seismicity of Algeria and adjacent regions during the twentieth century. Ann. Geofisc. 37 (4), 862p. http://hdl.handle.net/2122/1835.

Blakely, R.J., 1995. Potential Theory in Gravity and Magnetic Applications. Cambridge Univ. Press, Cambridge. https://doi.org/10.1017/CBO9780511549816.

Boubaya, D., Allek, K., Hamoudi, M., 2011. Is there a hidden near surface salt diapir in the Guelma Basin, north-east of Algeria ? J. Appl. Geophys. 73 (4), 348-356. https://doi.org/10.1016/j.jappgeo.2011.02.006.

Boudella, A., 1989. Étude gravimétrique des hauts plateaux sétifiens. Thèse de Magister, IST-USTHB, Alger-Algérie.

Boudiaf, A., Philip, H., Coutelle, A., Ritz, J.-F., 1999. Découverte d'un chevauchement d'âge quaternaire au sud de la grande kabylie (Algérie). Geodin. Acta 12 (2), 71-80. https://doi.org/10.1080/09853111.1999.11105332.

Bouillin, J.P., 1986. Le bassin Maghrébin : une ancienne limite entre l'Europe et l'Afrique à l'ouest des Alpes. Bull. Soc. Géol. de France 8, 547-558. II(4). https://doi.org/10.2113/gssgfbull.II.4.547.

Boukerbout, H., Abtout, A., Gibert, D., Henry, B., Bouyahiaoui, B., Derder, M.E.M., 2018. Identification of deep magnetized structures in the tectonically active Chlef area (Algeria) from aeromagnetic data using wavelet and ridgelet transforms. J. Appl. Geophys. 154, 167-181. https://doi.org/10.1016/j.jappgeo.2018.04.026.

Bournas, N., Galdeano, A., Hamoudi, M., Baker, H., 2003. Interpretation of the aeromagnetic map of Eastern Hoggar (Algeria) using the Euler deconvolution analytic signal and local wavenumber methods. J. Afr. Earth Sci. 37, 191-205. https://doi.org/10.1016/j.jafrearsci.2002.12.001. 
Bouyahiaoui, B., Sage, F., Abtout, A., Klingelhoefer, F., Yelles-Chaouche, K., Schnürle, P., Marok, A., Déverchère, J., Arab, M., Galve, A., Collot, J.Y., 2014. Crustal structure of the eastern Algerian continental margin and adjacent deep basin: implications for late Cenozoic geodynamic evolution of western Mediterranean. Geophys. J. Int. 201, 1912-1938. https://doi.org/10.1093/gji/ggv102.

Bracène, R., Frizon de Lamotte, D., 2002. The origin of intraplate deformation in the Atlas system of western and central Algeria: from Jurassic rifting to Cenozoic-Quaternary inversion. Tectonophysics 357 (1-4), 207-226. https://doi.org/10.1016/S00401951(02)00369-4.

Burrus, J., 1984. Contribution to a geodynamic synthesis of the provençal basin (North-Western Mediterranean). Mar. Geol. 55 (3-4), 247-269. https://doi.org/10.1016/0025-3227(84)90071-9.

Casula, G., Cherchi, A., Montadert, L., Murru, M., Sarria, E., 2001. The Cenozoic graben system Sardinia (Italy): geodynamic evolution from new seismic and field data. Mar. Pet. Geol. 18 (7), $863-$ 888. https://doi.org/10.1016/S0264-8172(01)00023-X.

Cherchi, A., Montadert, L., 1982. Oligo-miocene rift of sardinia and the early history of the western mediterranean basin. Nature 298 (5876), 736-739. https://doi.org/10.1038/298736a0.

Choukroune, P., Roure, F., Pinet, B., Ecors Pyrenees Team, 1990. Main results of the ecors Pyrenees profile. Tectonophysics 173, 411-423. https://doi.org/10.1016/0040-1951(90)90234-Y.

Dentith, M., Mudge, S.T., 2014. Geophysics for the Mineral Exploration Geoscientist. Cambridge University Press, UK 438 pp.

Dercourt, J., Ricou, L.E., Vrielynck, B., 1993. Atlas Tethys Palaeoenvironmental Maps. GauthierVillars, Paris 22 maps and 307 pp.

Dewey, J.-F., Cande, S., Pitman, W.C., 1989. Tectonic evolution of the India-Eurasia collision zone. Ecol. Geol. Helv. 82, 717-734.

Durand-Delga, M., 1969. Mise au point sur la structure du Nord-Est de la Berbérie. Publ. Serv. Carte géol. Algérie, NS. Bull. soc. Géol. fr. 7 (XIII), 328-337.

Ebinger, C.J., Keir, D., Bastow, I.D., Whaler, K., Hammond, J.O.S., Ayele, A., Miller, M.S., Tiberi, C., Hautot, S., 2017. Crustal structure of active deformation zones in Africa: implications for global crustal processes. Tectonics 36, 3298-3332. https://doi.org/10.1002/2017TC004526.

ECORS Pyrenees team, 1988. Deep reflection seismic survey across an entire orogenic belt, the ECORS Pyrenees profile. Nature 331, 508-511.

Finlay, et al., 2010. International geomagnetic reference field: the eleventh generation. Geophys. J. Int. 183, 1216-1230. https://doi.org/10.1111/j.1365-246X.2010.04804.x. 
Frizon de Lamotte, D., Saint Bezar, B.A., Bracene, R., Mercier, E., 2000. The two main steps of the Atlas building and geodynamics of the western Mediterranean. Tectonics 19 (4), 740-761. https://doi.org/10.1029/2000TC900003.

Frizon de Lamotte, D., Michard, A., Saddiqi, O., 2006. Quelques développements récents sur la géodynamique du Maghreb. C.R.Geosci. 338 (1-2), 1-10. https://doi.org/10.1016/j.crte.2005.11.006.

Fullea, J., Fernandez, M., Zeyen, H., 2008. FA2BOUG - A FORTRAN 90 code to compute Bouguer gravity anomalies from gridded free-air anomalies: application to the Atlantic-Mediterranean transition zone. Comput. Geosci. 34 (12), 1665-1681. https://doi.org/10.1016/j.cageo.2008.02.018.

Geosoft Inc, 2017. Oasis Montaj 9.2 (Software). Geosoft Inc, Toronto.

Grant, F.S., West, G.F., 1965. Interpretation Theory in Applied Geophysics. McGraw-Hill Book Co., New York, pp. 583.

Harbi, A., 2001. Analyse de la sismicité et mise en évidence d'accidents Actifs dans le Nord-Est Algerien. Mémoire de Magister. USTHB, Algérie.

Harbi, A., Benhallou, H., 2006. Evaluation de l’Aléa Sismique en Algérie du Nord par la Modélisation de l'Input Sismique dans les Zones Urbaines et l'Etablissement d'un Catalogue. PhD Diss. Univ. Algiers, Algérie.

Idres, M., 1983. Réseau de bases de référence et cartes des anomalies de Bouguer et isostatiques de l'Algerie du nord : Etude gravimétrique du massif d'Alger. Thèse de magistère. USTHB, Algérie.

Idres, M., Ydri, A., Lefort, J.P., Aïfa, T., 1996. Proposition d'un schéma structural du bassin du Chélif (Algérie) à partir des données gravimétriques. C. R. Acad. Sci. Paris 322 (IIa), 85-91.

Idres, M., Lefort, J.P., Aïfa, T., 1998. Modélisations gravimétriques et magnétiques des structures profondes du bassin du Chélif (Algérie). Bull. Serv. Geol. Alger 9 (1), 21-32.

Lagrula, J., 1951. Etude Gravimétrique de l'Algérie - Tunisie. Bull. Sev. Carte Géol. Algérie 4 (2), 114 .

Launay, N., Rochette, P., Quesnel, Y., Demory, F., Bezaeva, N.S., Lattard, D., 2017. Thermoremanence acquisition and demagnetization for titanomagnetite under lithospheric pressures. Geophys. Res. Lett. 44, 4839-4845. https://doi.org/10.1002/2017GL073279.

Launay, N., Quesnel, Y., Rochette, P., Demory, F., 2018. Iron formations as the source of the west african magnetic crustal anomaly. Front. Earth Sci. 6, 32. https://doi.org/10.3389/feart.2018.00032.

Le Pichon, X., Gaulier, J.-M., 1988. The rotation of Arabia and the Levant fault system. Tectonophysics 153 (1-4), 271-294. https://doi.org/10.1016/0040-1951(88)90020-0.

Leprêtre, A., Klingelhoefer, F., Graindorge, D., Schnürle, P., Beslier, M.O., Yelles, K., Déverchère, J., Bracène, R., 2013. Multiphased tectonic evolution of the Central Algerian margin from combined 
wide-angle and 2D reflection seismic data off Tipaza, Algeria. J. Geophys. Res. 118, 3899-3916. https://doi.org/10.1002/jgrb.50318.

Maouche, S., Bouhadad, Y., Harbi, A., Rouchiche, Y., Ousadou, F., Ayadi, A., 2019. Active Tectonics and Seismic Hazard in the Tell Atlas (Northern Algeria): A Review. https://doi.org/10.1007/978-3-31996794-3_10.

Mattauer, M., Tapponnier, P., Proust, F., 1977. Sur les mécanismes de déformation des chaînes atlasiques du Maroc. Bull. Soc. Géol. 521-526. Fr. S7-XIX(3). https://doi.org/10.2113/gssgfbull.S7XIX.3.521.

Mauffret, A., Frizon de Lamotte, D., Lallemant, S., Gorini, C., Maillard, A., 2004. E-W opening of the Algerian basin (Western Mediterranean). Terra. Nova 16 (5), 257-264. https://doi.org/10.1111/j.13653121.2004.00559.x.

Medaouri, M., Déverchère, J., Graindorge, D., Bracene, R., Badji, R., Ouabadi, A., Yelles-Chaouche, K., Bendiab, F., 2014. The transition from Alboran to Algerian basins (Western Mediterranean Sea): chronostratigraphy, deep crustal structure and tectonic evolution at the rear of a narrow slab rollback system. J. Geodyn. 77, 186-205. https://doi.org/10.1016/j.jog.2014.01.003.

Meghraoui, M., Doumaz, F., 1996. Earthquake-induced flooding and paleoseismicity of the El Asnam (Algeria) fault-related fold. J. Geophys. Res. 101, 17617-17644. https://doi.org/10.1029/96JB00650.

Meghraoui, M., Cisternas, A., Philip, H., 1986. Seismotectonics of the lower Chélif basin: structural background of the El-Asnam (Algeria) earthquake. Tectonics 5 (6), 809-836. https://doi.org/10.1029/TC005i006p00809.

Meliani, O., Bourmatte, A., Hamoudi, M., Haddoum, H., Quesnel, Y., 2016. Moho depth derived from gravity and magnetic data in the Southern Atlas Flexure (Algeria). J. Afr. Earth Sci. 121, 100-107. https://doi.org/10.1016/j.jafrearsci.2016.05.017.

Mihoubi, A., Schnürle, P., Benaissa, Z., Badsi, M., Bracene, R., Djelit, H., Geli, L., Sage, F., Agoudjil, A., Klingelhoefer, F., 2014. Seismic imaging of the eastern Algerian margin off Jijel: integrating wideangle seismic modelling and multichannel seismic pre-stack depth migration. Geophys. J. Int. 198 (3), 1486-1503. https://doi.org/10.1093/gji/ggu179.

Mokrane, A., Ait Messaoud, A., Sebai, A., Ayadi, A., Bezzeghoud, M., Benhallou, H., 1994. Les séismes en Algérie de 1365 à 1992. Publication du Centre de Recherche en Astronomie, Astrophysique et Géophysique, Département Etudes et Surveillance Sismique. ESS, C.R.A.A.G, Alger-Bouzaréah, Algérie 277 pp.

Nicolas, A., Polino, R., Hirn, A., Nicolitch, R., ECORS-CROP Working Group, 1990. ECORS-CROP traverse and deep structure of the western Alps: a synthesis. Mem. Soc. Geol. France Paris 156, 15-27.

Ousadou, F., Bezzeghoud, M., 2019. Seismicity of the Algerian Tell Atlas and the Impacts of Major Earthquakes. https://doi.org/10.1007/978-3-319-96794-3_11. 
Ouyed, M., Idres, M., Bourmatte, A., Boughacha, M.S., Samai, S., Yelles, A., Haned, A., Aïdi, C., 2011. Attempt to identify seismic sources in the eastern Mitidja Basin using gravity data and aftershock sequence of the Boumerdes (Algeria) earthquake. J. Seismol. 15, 173-189. https://doi.org/10.1007/s10950-010-9218-3.

Pavlis, N.K., Holmes, S.A., Kenyon, S.C., Factor, J.K., 2012. The development and evaluation of the Earth gravitational model 2008 (EGM2008). J. Geophys. Res. 117, B04406. https://doi.org/10.1029/2011JB008916.

Raoult, J., 1975. Évolution paléogéographique et structurale de la Chaine alpine entre le Golf de Skikda et Constantine (Algérie Orientale). Bull. Soc. Geol. France 7, 394-409. XVII, 3. https://doi.org/10.2113/gssgfbull.S7-XVII.3.394.

Roest, W.R., Srivastava, S.P., 1991. Kinematics of the plate boundaries between eurasia, iberia, and Africa in the north atlantic from the late cretaceous to the present. Geology 19 (6), 613-616. https://doi.org/10.1130/0091-7613(1991)019\%3c0613:KOTPBB\%3e2.3.CO;2.

Roure, F., Choukroune, P., Berastegui, X., Munoz, J.A., Villien, A., Matheron, P., Bareyt, M., Seguret, M., Camara, P., Deramond, J., 1989. Ecors deep seismic data and balanced cross sections: geometric constraints on the evolution of the Pyrenees. Tectonics 8 (1), 41-50. https://doi.org/10.1029/TC008i001p00041.

Samai, S., 2007. Etude gravimétrique de la Mitidja orientale. Thèse de Magistère. USTHB, Alger, Algérie.

Samai, S., Idres, M., Ouyed, M., Bourmatte, A., Boughacha, M., Bezghoud, M., Fernando Berges, J., 2017. A structural scheme proposal derived from geophysical data in the epicentral area of the Boumerdes (Algeria) earthquake of May 21, 2003. J. Afr. Earth Sci. 133, $138-147$. https://doi.org/10.1016/j.jafrearsci.2017.05.018.

Seber, D., Sandvol, E., Sandvol, C., Brindisi, C., Barazangi, M., 2001. Crustal model for the Middle East and North Africa region: implications for the isostatic compensation mechanism. Geophys. J. Int. 147, 630-638. https://doi.org/10.1046/j.0956-540x.2001.01572.x.

Stampfli, G.M., Marcoux, J., Baud, A., 1991. Tethyan margins in space and time. Palaeogeogr. Palaeoclimatol. Palaeoecol. 87 (1-4), 373-409. https://doi.org/10.1016/0031-0182(91)90142-E.

Telford, W.M., Geldart, L.P., Sheriff, R.E., 1990. Applied Geophysics. Cambridge University Press, Cambridge, UK.

Thébault, E., Finlay, C.C., Beggan, C.D., Alken, P., Aubert, J., Barrois, O., Bertrand, F., Bondar, T., Boness, A., Brocco, L., Canet, E., Chambodut, A., Chulliat, A., Coïsson, P., Civet, F., Du, A., Fournier, A., Fratter, I., Gillet, N., Hamilton, B., Hamoudi, M., Hulot, G., Jager, T., Korte, M., Kuang, W., Lalanne, X., Langlais, B., Léger, J.-M., Lesur, V., Lowes, F.J., et al., 2015. International geomagnetic reference field: the twelfth generation. Earth Planets Space 67, 79. https://doi.org/10.1186/s40623-0150228-9. 
Thiéblemont, D., et al., 2016. Geological map of Africa at 1:10m scale. Geological Map. CGMWBRGM.

Yelles, A., Domzig, A., Déverchère, J., Bracène, R., Mercier de Lépinay, B., Strzerzynski, P., Bertrand, G., Boudiaf, A., Winter, T., Kherroubi, A., Le Roy, P., Djellit, H., 2009. Plio-quaternary reactivation of the neogene margin off NW algiers, Algeria: the khayral Din bank. Tectonophysics 475 (1), 98-116. https://doi.org/10.1016/j.tecto.2008.11.030.

Zerdazi, A., 1990. Étude gravimétrique du Mole d'Ain-M'lila et de l'Atlas Saharien septentrional oriental. PhD Thesis. Lausanne University.

Zeyen, H., Ayarza, P., Fernandez, M., Rimi, A., 2005. Lithospheric structure under the western africanEuropean plate boundary: a transect across the Atlas mountains and the gulf of cadiz. Tectonics 24, TC2001. https://doi.org/10.1029/2004TC001639.

Appendix A. Supplementary data

Supplementary data to this article can be found online at https://doi.org/10.1016/j.jafrearsci.2019.103566 